\title{
Adaptation of New Rice High Yielding Varieties on New Constructed Irrigated Rice Field Affected by Sea Water Intrusion in West Tanjung Jabung District, Jambi
}

\author{
Busyra Buyung Saidi, Jon Hendri, Suharyon and Hendri Purnama \\ Assessment Institute of Agricultural Technology (AIAT) of Jambi, Indonesia \\ e-mail: busyra_sidi@yahoo.co.id
}

Received March 09, 2020; Revised August 4, 2020; Accepted 07 September 2020

\begin{abstract}
Assessment adaptation of several new superior rice varieties on new rice fields affected by seawater intrusion was carried out in Tungkal Ilir Subdistrict, West Tanjung Jabung District, from April to October 2018. The study applied randomized block designs (RBD) with four replications. The treatments consisted of four new rice high yielding varities suitable for tidal/swamps areas namely Inpara 3, Inpara 8, Inpara 9, and Inpari 34 Salin Agritan, and one local rice variety (Londo) as control. Three stems seedlings per clump were planted at the age of 21-25 days, using a 4:1 Legowo planting system. Fertilizer application consisted of basic fertilizer (1.0 Mg ha-1 of lime, $2.5 \mathrm{Mg} \mathrm{ha}^{-1}$ of manure, and $75 \mathrm{~kg} \mathrm{ha}^{-1}$ of urea) and supplementary fertilizer (SP-36 $150 \mathrm{~kg} \mathrm{ha}^{-1}$ and $\mathrm{KCl} 125 \mathrm{~kg} \mathrm{ha}^{-1}$ ), Urea supplementation is given based on observations with a leaf color chart (LCC). The results of the study showed that the four new rice HYVs were more adapted as compared to the local rice variety. The performance of the tested new rice HYVs showed quite a good growth appearance and productivity. The highest production was obtained in Inpari 34 Salin Agritan variety 2.85 $\mathrm{Mg} \mathrm{ha}^{-1}$, while Inpara 3, Inpara 8, and Inpara 9 ranged between 2.0 and $2.1 \mathrm{Mg} \mathrm{ha}^{-1}$, while the local variety's productivity was $1.9 \mathrm{Mg} \mathrm{ha}^{-1}$.
\end{abstract}

Keywords: Jambi, new HYV of rice, productivity, saline rice field

\begin{abstract}
ABSTRAK
Pengkajian Uji Adaptasi beberapa varietas unggul padi baru pada sawah bukaan baru yang terkena intrusi air laut telah dilakukan di Kecamatan Tungkal Ilir, Kabupaten Tanjung Jabung Barat dari bulan April sampai Oktober 2018. Pengujian menggunakan Rancangan Acak Kelompok (RAK) dengan empat ulangan. Perlakuan terdiri dari empat varietas unggul padi baru yang cocok untuk daerah pasang surut / rawa yaitu Inpara 3, Inpara 8, Inpara 9 dan Inpari 34 Agritan Salin, serta satu varietas padi lokal (Londo) sebagai kontrol. Penanaman tiga batang per rumpun pada umur 21 hari dengan sistem tanam legowo 4: 1. Pemupukan terdiri dari pupuk dasar $\left(1,0 \mathrm{Mg} \mathrm{ha}^{-1} \mathrm{kapur}, 2,5 \mathrm{Mg}\right.$ ha1 pupuk kandang, dan $75 \mathrm{~kg} \mathrm{ha}^{-1}$ urea) dan pupuk susulan (SP-36 $150 \mathrm{~kg} \mathrm{ha}^{-1}$ dan $\mathrm{KCl} 125 \mathrm{~kg} \mathrm{ha}^{-1}$ )., pemupukan urea susulan berdasarkan hasil pengukuran dengan bagan warna daun. Hasil pengkajian menunjukkan bahwa keempat HYV padi baru lebih beradaptasi dibandingkan dengan varietas padi lokal. Performa HYV padi baru yang diuji menunjukkan penampilan pertumbuhan dan produktivitas yang cukup baik. Produksi tertinggi diperoleh pada varietas Inpari 34 Salin Agritan 2,85 $\mathrm{Mg} \mathrm{ha}^{-1}$, sedangkan Inpara 3, Inpara 8, dan Inpara 9 berkisar antara 2,0 dan 2,1 $\mathrm{Mg} \mathrm{ha}^{-1}$, sedangkan produktivitas varietas lokalnya adalah $1,9 \mathrm{Mg} \mathrm{ha}^{-1}$.
\end{abstract}

Kata Kunci: Jambi, produktivitas, sawah asin

\section{INTRODUCTION}

Degradation of agricultural land in Indonesia due to salinization has become one of the national

J Trop Soils, Vol. 25, No. 3, 2020: 119-126

ISSN 0852-257X; E-ISSN 2086-6682 issues (Las et al. 2006). In the dry season, land salinity increases due to intrusion of seawater through channels, streams, or swamps. Agricultural land that is affected by seawater intrusion can reach up to $20 \mathrm{~km}$ from the coastline (Erfandi et al. 2011). The mapping of saline land in Indonesia has not been done much, but there have been many identified 
agricultural lands that are saline. The 2004 tsunami in Aceh increased land salinity (ECe 2-40 dS m$~^{-1}$ ) which damaged more than 120,000 ha of agricultural land (Rachman et al. 2008). The effect of salinity on agricultural land was considered a serious threat to global food supply now and in the future. More than $7 \%$ or 77 million ha of the total land in the world (930 million ha), and more than $20 \%$ of agricultural land currently has been salinized, some of which was irrigated land (Hariadi et al. 2010). One of the measurable indications in determining a land experiencing a threat and potential salinity was the value of electrical conductivity (EC) of land and irrigation water. The soil has experienced salinity if soil ECe value $>4 \mathrm{dS} \mathrm{m}^{-1}$ (FAO 2005).

According to Ritung et al. 2011, salinity is the amount of soluble salt content in the soil which is reflected by the electrical conductivity. Soil salinity is measured based on the power of the soil to electrical conductivity (EC) and is expressed in units of $\mathrm{mS} \mathrm{cm}^{-1}$ or $\mathrm{dS} \mathrm{m}^{-1}$ at $25^{\circ} \mathrm{C}$ (Rusd 2011).

Salinity is one of the limiting factors of plant growth and productivity. Most of plants are sensitive to salinity due to a high salt content in the soil (Dogar et al. 2012). Salinity affects almost all stages of plant growth, namely germination, seedling, vegetative and generative growth (Nawaz et al. 2010). The high content of dissolved salts in saline soils, especially $\mathrm{Na}$ ions, causes a decrease in the availability of $\mathrm{Ca}, \mathrm{Mg}$, and $\mathrm{K}$. Besides, plant growth is inhibited due to the osmotic and toxic effects of excessive salt ions (Wahyuningsih et al. 2017).

Most of the research indicated that the germination phase of rice is the most sensitive phase for salinity stress compared to other phases. Rice tolerance increases in the vegetative phase and becomes sensitive again in the reproductive phase ( $\operatorname{Rad}$ et al. 2011). The sensitivity of rice to salinity stress is different among several varieties.

Efforts that can be made to reduce the damaging effects of saline soils are to improve saline soils through chemical and biological treatment. Chemically, with the addition of soil enhancers such as gypsum or $\mathrm{CaSO}_{4}$ (Makoi and Verplancke 2010), the addition of potassium can also improve the adverse effects of saline soils (Karimi et al. 2009). Whereas biologically it can be done by adding organic material/organic fertilizer such as manure (Kusmiyati et al. 2009); halophyte planting on saline soils such as Leptochloa fusca grass (Ahmad and Chang 2002).

According to Oyiga et al. (2016), the most efficient way to overcome the salinity problems is by planting tolerant varieties. Plants have certain mechanisms in overcoming salinity stress: 1) tolerance to osmotic pressure, 2) ion exclusion, and 3) tolerance of plant tissue (Roy et al. 2014). The use of tolerant varieties can reduce growth reduction and yield loss of rice that is salted by rice (Hariadi et al. 2010).

High yielding variety rice is one of the main technology components which is a very dominant in increasing domestic rice productivity and production. Paddy plants have a relatively broad ecological spectrum, being cultivated in various types of agroecosystems, and include the socio-cultural aspect. Each type of agroecosystem has different problems and constraints, such as chemical poisoning, drought, low temperatures, certain pests and diseases (Suhartini 2004).

The Indonesian Agency for Agricultural Research and Development (AARD) has released several rice varieties, which are tolerant to climate change, including high yield varieties tolerance to drought; Inpari 18, Inpari 19, Inpari 20, with potential yields of 8.0-9.5 $\mathrm{Mg} \mathrm{ha}^{-1}$. Rice varieties of submergence-tolerant rice are Inpari 29, Inpari 30, Ciherang Sub-1, Inpara 4, Inpara 5. While, rice varieties tolerance to salinity are Dendang, Lambur, and Siak Raya, Inpari 34 Saline Agritan, Inpari 35 Saline Agritan, Inpari Unsoed 79 Agitan, Inpari 42 Agrarian GSR, Inpari 43 Agritan GSR, Inpari 44 Agritan. In contrast to other Inpari varieties, Inpari 34 Agricultural Salts and Inpari 35 Agricultural Salts are tolerant to salinity in the seedling phase, and also has other advantages, namely a high yield which reach 9.5 and $9.6 \mathrm{Mg} \mathrm{ha}^{-1}$, resistance to blast disease, and somewhat resistance to pests WBC (AARD 2015; 2019; ICFORD 2019).

The development of rice in saline land is still experiencing problems because of the limited varieties which are suitable to be developed. According to Ritung et al. (2011), if the value of $\mathrm{ECe}>6 \mathrm{dS} \mathrm{m}{ }^{-1}$, then the growth of rice plants will be stunted (not suitable).

Rice is a crop that is classified as vulnerable to the environment of salinity, soil salinity of $2 \mathrm{dS} \mathrm{m}^{-1}$ is considered optimal, but if 4-6 dS m$~^{-1}$ is classified as marginal (Muliawan 2016). Yield loss can reach more than $50 \%$ if the growing media has an ECe of $7.2 \mathrm{dS} \mathrm{m}^{-1}$ or if the exchangeable sodium percentage (ESP) value is around 20\% (Abdullah et al. 2001).

Rice susceptibility to salinity begins at the nursery phase, is tolerant at the vegetative phase, then becomes vulnerable again when entering the reproductive phase, especially in seed filling. The initial symptoms of crop damage by salinity are: (i) the color of the leaves is reddish yellow compared to the normal color (chlorosis); (ii) smaller leaf size; (iii) stems with shorter leaf spacing and (iv) dead leaf edges dry brownish (Munns 2002). 
The damaging effect of salinity on plants is related to the high osmotic pressure of water, the imbalance between $\mathrm{Na}$ and $\mathrm{K}, \mathrm{Ca}, \mathrm{Mg}$ ions, and is related to the decrease in $\mathrm{N}$ and $\mathrm{P}$ uptakes. High $\mathrm{Na}^{+}$concentration in soil solution suppresses nutrient ion activity and causes $\mathrm{Na}^{+} / \mathrm{Ca}^{2+}$ ratio or extreme $\mathrm{Na}^{+} / \mathrm{K}^{+}$, which can interfere with the absorption of $\mathrm{Ca}$ and $\mathrm{K}$ ions (Grattan and Grieve 1999).

Based on the description above, it is necessary to study the adaptation test of several new superior varieties that are tolerant to the condition of paddy fields which are affected by seawater intrusion.

\section{MATERIALS AND METHODS}

\section{Study Sites and Soil Analysis}

The assessment was carried out on new open paddy fields affected by seawater intrusion in Nibung Jaya Village, Tungkal Ilir Subdistrict, Tanjung Jabung Barat District, Jambi from April to October 2018. Analysis of soil samples were conducted at the Bogor Soil Research Institute Laboratory. The analysis procedures are based on Technical Guidance on Soil, Plant, Water, and Fertilizer Chemical Analysis (Eviati and Sulaeman 2012).

\section{Experimental Set Up and Fertilization}

The study used a Randomized Block Design (RBD) with 4 (four) replications. The treatment consisted of adaptation tests for 5 varieties of lowland rice: Inpara 3, Inpara 8, Inpara 9, Inpari 34 Agritan Salinity, and Londo (local variety). Fertilizer recommendations were determined based on the results of soil analysis using the swamp soil test (PUTR) (Soil Research Institute 2017), which were $1.0 \mathrm{Mg}$ lime ha ${ }^{-1}, 5.0 \mathrm{Mg}$ manure ha-1, $200 \mathrm{~kg}$ Urea $\mathrm{ha}^{-1}, 150 \mathrm{~kg} \mathrm{SP}-36 \mathrm{ha}^{-1}$, and $100 \mathrm{~kg} \mathrm{KCl} \mathrm{ha}^{-1}$. Lime and manure were given 10 days before planting. At the time of planting $150 \mathrm{~kg} \mathrm{SP}-36 \mathrm{ha}^{-1}$ and $50 \mathrm{~kg}$ $\mathrm{KCl} \mathrm{ha}^{-1}$ were applied. Whereas, a $1 / 3$ part of Urea fertilizer is applied at planting time, a $1 / 3$ part at 4 weeks after planting (WAP), and a $1 / 3$ part at 6 WAP. Urea supplementation was given based on observations with a leaf color chart (LCC).

\section{Plant planting and maintenance}

Planting was done by transplanting with young seedlings 20 days of 2-3 stems/clumps with the Jajar Legowo 4:1 planting system.

Implementation of field activities ranged from seed preparation to harvest and post-harvest refers to the Integrated Crop Management (ICM) approach consisting of labeled seeds, 20 day-old seeds, 3 seedlings per clump, legowo row planting system 4:1, Pest Control and ICM, and the harvest was carried out when the grain had yellowed 95\% (33-36 days after flowering) (AARD 2007). Observations were made on the soil chemical properties before the assessment, plant height, number of productive tillers, number of grains per panicle, and yields per hectare.

\section{Data Analysis}

Data were analyzed using the MINITAB 15 application program (Syukri 2009) for analysis of variance (ANOVA). If the treatments in ANOVA results had a significant difference, then the analysis was continued with Duncan's Multiple Range Test (DMRT) with a significant level of 5\% (Steel and Torrie 1991).

\section{RESULTS AND DISCUSSION}

\section{Soil Chemical Characteristics}

The new open paddy land in Sungai Nibung Village, Tungkal Ilir District, West Tanjung Jabung District can be categorized as saline land, where the value of ECe is $4.18 \mathrm{dS} \mathrm{m}^{-1}$ (Table 1). According to Djukri (2009), saline soil generally has an interelectric power value under conditions of electric saturation equal to or more than $4.0 \mathrm{dS} \mathrm{m}^{-1}$, and the percentage of sodium is exchanged (exchangeable sodium percentage, ESP) $>15 \%$ and soil $\mathrm{pH}$ value around 8.5. Such land has several obstacles related to the suitability of plant growth such as 1) low osmotic pressure of plants; 2) low $\mathrm{N}$ and $\mathrm{K}$ elements; 3) high $\mathrm{Na}^{+}$content; and 4) high soil $\mathrm{pH}$ (FAO 2005).

Based on soil analysis, the assessment site is alkaline ( $\mathrm{pH}$ 8.6), soil salinity is $2090 \mathrm{mg} \mathrm{L}^{-1}$ (very high), electrical conductivity is $4,180 \mathrm{dS} \mathrm{m}^{-1}$ (very high), $\mathrm{C} / \mathrm{N}$ is moderate, $\mathrm{P}_{2} \mathrm{O}_{5}$ Bray 1 is moderate, $\mathrm{K}_{2} \mathrm{O}$ is very high, $\mathrm{Ca}$ is moderate, $\mathrm{CEC}$ is moderate, and base saturation is very high. Based on the soil nutrient status, the fertility status of the soil chemical properties in the assessment location is classified as moderate to high. But because plants are gripped by soil salinity, plant growth will be disrupted.

Salinity can inhibit plant growth and development due to the effects it causes. According to Chaum and Kirdmanee (2011) in Arifiani et al. (2018), salinity caused plants to be poisoned by $\mathrm{Na}^{+}$ and $\mathrm{Cl}^{-}$ions which caused osmotic and ionic stresses in cells that would inhibit plant growth and development. The effectiveness of $\mathrm{Na}^{+}$in the soil can inhibit the absorption of $\mathrm{K}^{+}$(Harborne 1982 cited by Djukri 2009). High salinity would reduce the availability of $\mathrm{K}^{+}$and $\mathrm{Ca}^{++}$in soil solutions, so it would 
Table 1. Soil properties under the influence of sea water intrusion of Sungai Nibung, Tungkal Ilir, West Tanjung Jabung

\begin{tabular}{|c|c|c|}
\hline Soil Property & Value & Criteria*) \\
\hline $\mathrm{pH} \mathrm{H} \mathrm{H}_{2} \mathrm{O}$ & 8.56 & Alkalis \\
\hline ECe $\left(\mathrm{dS} \mathrm{m}^{-1}\right)$ & 4.180 & Very high \\
\hline Salinity $\left(\mathrm{mg} \mathrm{L}^{-1}\right)$ & 2.090 & Very high \\
\hline \multicolumn{3}{|l|}{ Organic matter } \\
\hline $\mathrm{C}(\%)$ & 5.75 & Very high \\
\hline $\mathrm{N}(\%)$ & 0.32 & Medium \\
\hline $\mathrm{C} / \mathrm{N}$ & 15 & Medium \\
\hline $\mathrm{P}_{2} \mathrm{O}_{5}(\mathrm{ppm})$ & 22.4 & Moderate \\
\hline $\mathrm{K}_{2} \mathrm{O}(\mathrm{ppm})$ & 1043 & Very high \\
\hline \multicolumn{3}{|c|}{ Cation Exchange Rate $\left(\mathrm{cmol}^{(+)} \mathrm{kg}^{-1}\right)$} \\
\hline $\mathrm{Ca}\left(\mathrm{cmol}^{(+)} \mathrm{kg}^{-1}\right)$ & 7.43 & Moderate \\
\hline $\operatorname{Mg}\left(\mathrm{cmol}^{(+)} \mathrm{kg}^{-1}\right)$ & 16.80 & Very high \\
\hline $\mathrm{K}\left(\mathrm{cmol}^{(+)} \mathrm{kg}^{-1}\right)$ & 1.77 & Very high \\
\hline $\mathrm{Na}\left(\mathrm{cmol}^{(+)} \mathrm{kg}^{-1}\right)$ & 10.04 & Very high \\
\hline $\mathrm{CEC}\left(\mathrm{cmol}^{(+)} \mathrm{kg}^{-1}\right)$ & 19.53 & Medium \\
\hline Base saturation (\%) & $>100$ & Very high \\
\hline
\end{tabular}

*) Source: Eviati dan Sulaiman (2012)

also reduce the concentration of $\mathrm{Fe}$ ions in leaves and roots due to reducing absorption of $\mathrm{Fe}$ in high salinity conditions (Grattan and Grieve 1999).

The high salt content in the soil causes a disruption of plant growth, crop productivity, and physiological functions of the plant normally, especially in types of crops. Soil salinity suppresses plant growth processes and its effects will inhibit cell enlargement and division, protein production, and addition of plant biomass. Plants that experience salt stress generally do not show a response in the form of direct damage but the form of depressed plant growth and changes slowly (Sipayung 2003).

The observation results on the growth and production components of rice varieties tested on new open paddy fields affected by seawater intrusion is presented in Table 2. It was likely that there was no significant difference in plant height of the tested varieties. Plant height achieved by paddy plants was classified as not good because the disruption of nutrient availability due to high levels of $\mathrm{Na}$ and $\mathrm{Ca}$. The results of soil analysis show that the soil in the study site has a high soil $\mathrm{pH}(\mathrm{pH} 8.6$, classified as Alkali), a very high soil salinity $\left(2,090 \mathrm{mg} \mathrm{L}^{-1}\right)$, a very high electrical conductivity $\left(4.180 \mathrm{dS} \mathrm{m}^{-1}\right)$, and cause a disturbing plant growth. Following Muharam and Saefudin (2016), there were no differences in the plant height of paddy plants influenced by some soil ameliorants in the constructed irrigated rice field of saline soil. This shows that plants from the beginning of growth have experienced salt stress. By the opinion of Mozafar (2007) who stated that the symptoms exhibited by plants are a result of soil conditions of the land. The high $\mathrm{pH}$ of 8.56 resulted in a lack of nutrients that can be seen from the appearance of a dwarf and yellowing plant growth. Besides that, the saline soil condition causes the plants experience water stress so that the leaf tips like burning, very slow growth, as well as, the plants experience moisture stress, so they become stunting, as shown in plant height observed.

Salinity affects almost all stages of plant growth, namely germination, seedling, vegetative and generative growth (Nawaz et al. 2010). The high content of dissolved salts in saline soils, especially $\mathrm{Na}$ ions, cause a decrease in the availability of $\mathrm{Ca}, \mathrm{Mg}$, and $\mathrm{K}$ (Wahyuningsih et al. 2017). As shown from the soil analysis in Table 1, where very high $\mathrm{pH}$, salinity, and sodium will disturb plant growth. Also, plant growth was inhibited due to the osmotic and toxic effects of excessive salt ions. According to Mindari (2009), salinity suppresses plant growth processes so that will affect to the inhibition of cell enlargement and division, protein production, and the addition of plant biomass. Symptoms of plant growth on soils with high salinity levels are abnormal growths such as leaves drying at the tips and symptoms of chlorosis. These symptoms arise because the high concentration of dissolved salts that cause a decrease in the potential of the soil solution so that plants lack of water. The soil physical properties are also affected, among others, the shape of the structure, water holding capacity, and soil permeability. Further added by Xu et al (2013), physiologi- 
Table 2. Adaptation test of several new HYV and local rice varieties in a new constructed irrigated rice field in marginal land affected by seawater intrusion in Sungai Nibung Village.

\begin{tabular}{llccccc}
\hline No. & Variety & $\begin{array}{c}\text { Plant Height } \\
(\mathrm{cm})\end{array}$ & Tiller (trunk) & $\begin{array}{c}\text { Productive } \\
\text { tiller } \\
\text { (trunk })\end{array}$ & $\begin{array}{c}\text { Grain per } \\
\text { panicle }\end{array}$ & $\begin{array}{c}\text { Yield } \\
\left(\mathrm{Mg} \mathrm{ha}^{-1}\right)\end{array}$ \\
\hline 1. & Inpara 3 & $95.30 \mathrm{a}$ & $19.16 \mathrm{~b}$ & $15.41 \mathrm{a}$ & $92.58 \mathrm{~b}$ & $2.36 \mathrm{a}$ \\
2. & Inpara 8 & $93.48 \mathrm{a}$ & $18.00 \mathrm{a}$ & $14.75 \mathrm{a}$ & $83.67 \mathrm{a}$ & $2.07 \mathrm{a}$ \\
3. & Inpara 9 & $95.40 \mathrm{a}$ & $17.75 \mathrm{a}$ & $14.58 \mathrm{a}$ & $86.42 \mathrm{ab}$ & $2.34 \mathrm{a}$ \\
4. & Inpari 34 & $97.60 \mathrm{a}$ & $21.00 \mathrm{c}$ & $17.66 \mathrm{~b}$ & $100.08 \mathrm{c}$ & $2.85 \mathrm{~b}$ \\
5. & Londo & $95.55 \mathrm{a}$ & $17.17 \mathrm{a}$ & $13.75 \mathrm{a}$ & $85.17 \mathrm{a}$ & $1.90 \mathrm{a}$ \\
\hline
\end{tabular}

cal and metabolic functions will also be disrupted by the toxicity of salt ions, including a decrease in the rate of photosynthesis, the rate of transpiration, the protein synthesis, the fat metabolism, the cell division, the hormonal imbalances, and a decrease in the activity of several enzymes such as esterase, isocitric dehydrogenase, and catalase.

There are significant differences in the maximum number of tillers, productive tillers, grain per panicle, and grain yield per hectare between Inpari 34 Salin Agritan and Inpara 9, Inpara 8 Inpara 3 , and Londo varieties. While between Inpara 3, Inpara 8, Inpara 9, and Londo (local varieties), there were no significant differences. Production of new HYV of rice generally reaches production above 2 $\mathrm{Mg} \mathrm{ha}^{-1}$, whereas local varieties (Londo) can only produce dry grain harvested less than $2 \mathrm{Mg} \mathrm{ha}^{-1}$, i.e. $1.90 \mathrm{Mg} \mathrm{ha}^{-1}$ (Table 1). This shows that HYV (Inpara) can adapt to saline soil conditions that have never been planted by paddy before compared to the Londo (local) variety.

The number of productive tillers among the rice varieties tested showed a significant difference between Inpari 34 Salin Agritan and other varieties. It was likely that the Inpari 34 Salin Agritan variety was more tolerant than other varieties. This tolerance was also seen in other growth indicators such as the amount of grain per panicle and the production. This diversity occurs because each variety has a different genetic potential in responding to the growth environment, namely dissolved salts in seawater mixed with river water that periodically enters the paddy fields.

The low number of tillers were due to high electrical conductivity $(\mathrm{Ec})$ of saline paddy soils which was $4.18 \mathrm{dS} \mathrm{m}^{-1}$ (very high) as shown in Table 1. According to Mindari (2009), the response of plants experiencing salt stress, in general, was not directly damaging but in the form of plants stunted growth and change slowly. In a study conducted by Motamed (2008), there was a marked decrease in rice productivity in line with the increase in salinity value. The smaller number of tillers, shorter plant height, and reduced weight of 100 grains of rice were the effects caused by salinity. Chaum et al. (2011) stated that salinity causes plants to be poisoned by $\mathrm{Na}^{+}$and $\mathrm{Cl}^{-}$ions causing osmotic and ionic stress in cells so that it will inhibit plant growth and development.

Differences in genetic traits affect the number of tillers which have a significant effect on harvest time where the highest number of tillers was in the Inpari 34 Salin Agritan variety (17.66 tillers) and the lowest was in the Londo variety (13.75 tillers). Sitompul and Guritno (1995) stated that in general plants have the same phenotype and genotive differences. Variety differences are quite large affecting genetic differences or environmental differences or both. The difference in genetic makeup was one of the factors causing diversity in plant appearance. The genetic program that would be expressed at a different phase of growth can be expressed in a variety of plant traits, which included the shape and function of plants that produce plant growth diversity.

Inpari 34 Salin Agritan was one of the new superior varieties of irrigated paddy rice released by the AARD in 2015, suitable for planting in the lowlands to a height of 500 meters above sea level ( $\mathrm{m}$ asl). It is a salt-resistant paddy in the seedling phase at $12 \mathrm{dS} \mathrm{m}^{-1}$ stress, and has a high production potential of $8.1 \mathrm{Mg} \mathrm{ha}^{-1}$ with an average production of $5.1 \mathrm{Mg} \mathrm{ha}^{-1}$. The age of harvest was only 102 days after spread and it was classified as a variety that was preferred by farmers in terms of harvest age (IсғовD 2017). The results of testing by Central Java AIAT, precisely the Kendal coast in Purwokerto Village and Turunrejo Village, Brangsong District, harvested Inpari 34 rice varieties in one stretch were able to produce around $7-9 \mathrm{Mg}$ $\mathrm{ha}^{-1}$. While the production achieved by other rice plants in the same land was only able to produce 
rice production of 4-6 tons per hectare (ICFORD 2019).

Inpari 34 and Inpari 35 Salin Agritan varieties have better adaptation rates compared to other Inpara and Inpari. Both of these varieties produce a higher number of tillers and the panicles have started to have grain contents, $6 \%$, and $8 \%$ respectively, while other varieties produce $100 \%$ hollow seeds. According to the description, both varieties are tolerant of salinity in the seedling phase at a stress of $12 \mathrm{dS} \mathrm{m}^{-1}$, but conditions in the field show that both varieties are growing very depressed during the dry season.

According to Rachmawati (2000), plant adaptation to salinity can be demonstrated by the formation of proline and various other free amino acids in cells, which play a role in increasing resistance to salt stress. The mechanism for tolerance to salinity stress can be the exclusion or inclusion of salt. Adaptation through salt exclusion requires an avoidance mechanism from internal water deficits. Whereas adaptation through salt inclusion requires either a high tolerance of tissue to $\mathrm{Na}^{+}$and $\mathrm{Cl}^{-}$or avoidance from high salt concentrations in the tissue.

Sembiring and Gani (2010) stated that tidal land was strongly influenced by tidal movements and had varying salinity values. This situation, as explained by Sipayung (2003), would inhibit the growth of roots, stems, and leaf area due to salt stress, namely metabolic imbalance caused by ion poisoning $\left(\mathrm{Na}^{+}\right)$and nutrient deficiency $(\mathrm{N}, \mathrm{P}$, and $\mathrm{K})$. Besides, the rainfall that falls to the earth and was absorbed into the soil would bind to the cation of salt in the soil so that it would reduce the concentration of salt in the soil. This was consistent with Widiarta's research (2016) who found that plants need sufficient water contents in the soil to be able to do growth. Soil conditions with low water capacity and high salt accumulation make the plants were difficult to grow and would cause death. This condition was found during the assessment where the rainfall was very low starting from the time of planting to 40 days after planting so that it would affect subsequent plant growth.

Salinity stress is an abiotic stress that can affect crop productivity and quality. Root, stem, and leaf growth area are reduced due to metabolic imbalance caused by $\mathrm{NaCl}$ ion poisoning, osmotic stress, and nutrient deficiency (Sembiring and Gani 2010). The ionic stress results in inhibited the absorption of potassium and phosphorus nutrients. Furthermore, Sembiring et al. (2008) stated that the effect of excessive salt on rice plants is reduced the germination speed, the plant height and the number of tillers, poor root growth, increased seed sterility, reduced 1000 grain weight and total protein content in seeds due to the absorption of $\mathrm{Na}$ excessive, reduced biological $\mathrm{N}_{2}$ tethering and slow soil mineralization. Excess $\mathrm{Na}^{+}$concentration would slow the process of seed germination, inhibit plant height growth, reduce the number of tillers, stunted root growth, and reduced the weight of 1000 grains (Utama 2015).

In the germination phase, saline stress inhibits the germination process due to the entry of salt ions to a toxic level into the embryo (Kronzucker et al. 2013). The high salt ion content in plant cells can also cause changes in hydration and protein precipitation (Swapna 2003). Several studies have shown that during the germination phase of paddy is the most sensitive to salinity stress compared to other phases. Paddy tolerance increases in the vegetative phase and becomes sensitive again in the reproductive phase ( $\operatorname{Rad}$ et al. 2011). The sensitivity of rice to salinity stress was different among several varieties.

Interchangeable salts or $\mathrm{Na}$ would affect the properties of the soil if there was excessive conditions in the soil, where the $\mathrm{Na}$ content before the assessment was 10.04 me $100 \mathrm{~g}^{-1}$ (very high) (Table 1). Increasing the concentration of dissolved salt in the soil would increase osmotic pressure thus inhibiting the absorption of water and nutrients that take place through the osmosis process. The amount of water that enters the roots would be reduced, resulting in depletion of the amount of water supply in plants (Follet et al. 1981 in Mindari 2009). Increased salinity causes a decrease in the production and productivity of crops. Increased soil salinity to $6-10 \mathrm{dS} \mathrm{m}^{-1}$ causes a decrease in grain yield by up to $50 \%$ (Brinkman and Singh, 1982 in Sembiring and Gani 2010). Crops generally have a tolerance of salinity up to $3 \mathrm{dS} \mathrm{m}^{-1}$, in the field often an increase in salinity of 4-8 $\mathrm{dS} \mathrm{m}^{-1}$ occurs so that most plants experience salt stress (Shofiyanti and Wahyunto 2006).

From the results of this study, in general, the level of production obtained was still below the average yield potential of varieties (HYVs) description in the normal conditions, average 4-6 $\mathrm{Mg} \mathrm{ha}^{-1}$. However, from the production of each variety, it can be seen that it can still adapt to very high soil salinity conditions, namely between 2.07 to $2.85 \mathrm{Mg} \mathrm{ha}^{-1}$, while local varieties (londo) produce below $2.0 \mathrm{Mg} \mathrm{ha}^{-1}$.

\section{CONCLUSIONS}

New constructed irrigated rice fields in Nibung Jaya Village, Tungkal Ilir Subdistrict, West Tanjung Jabung District are classified as saline with 
characteristics of $\mathrm{pH} 8.56$ electrical conductivity of $4.18 \mathrm{dS} \mathrm{m}^{-1}$. Another chemical property was the high cation value of calcium and sodium can be exchanged for $7.43 \mathrm{cmol}^{(+)} \mathrm{kg}^{-1}$ and $10.04 \mathrm{cmol}^{(+)} \mathrm{kg}^{-1}$.

New HYV rice Inpara 3, 8, and 9 and Inpari 34 Saline Agritan was quite adaptable to saline land compared to local varieties (Londo).

From the adaptation test results of several new HYV rice (VUB) on marginal land affected by seawater intrusion, Inpari 34 Salin Agritan variety shows better adaptability compared to Inpara 3, Inpara 8, Inpara 9, and Londo (local) varieties.

\section{ACKNOWLEDGEMENTS}

The author would like to thank Ratna Rubiana, a Plant Pest Researcher and Rustan Hadi for their assistance as field technicians at the Jambi Assesment Institute Agricultural Technology (AIAT) and M. Taha as officers from the Jambi Province Food Crops and Horticultural Protection Agency.

\section{REFERENCES}

Abdullah Z, MA Khan and TJ Flowers. 2001. Causes of sterility in seed set of rice under salinity stress. $J$ Agronomy Crop Sci 187: 25-32.

Ahmad R and MH Chang. 2002. Salinity control and environmental protection through halopythes. $J$ Drainage Water Manag 6: 17-25.

AARD [Badan Litbang Pertanian]. 2019. Dekripsi Varietas Unggul Baru Padi. Inbrida Padi Sawah (INPARI), Hibrida Padi (HIPA), Inbrida Padi Gogo (INPAGO), Inbrida Padi Rawa (INPARA). In: S Priatna, Satoto, Rahmini, N Agustian, DD Handoko, Suprihanto, A Guswara and Suharna (eds). Badan Penelitian dan Pengembangan Pertanian. Kementerian Pertanian. $107 p$ (In Indonesia).

Arifiani FN, B Kurniasih and R Rogomulyo. 2018. R. Rogomulyo. 2018. Pengaruh bahan organik terhadap pertumbuhan dan hasil padi (Oryza sativa L.) Tercekam Salinitas. J Vegetalika 7: 30-40. (in Indonesian)

AARD [Agency for Agricultural Research and Development]. 2007. Pengelolaan Tanaman Terpadu (PTT) Padi Lahan Rawa Lebak. Pedoman Bagi Penyuluh Pertanian. In: Suyamto, H Pane, Suwarno, B Kustianto, AK Makarim, H Suharso dan H Sembiring (eds). Badan Litbang Pertanian. Departemen Pertanian. 42p. (in Indonesian)

AARD [Agency for Agricultural Research and Development]. 2015. Deskripsi Varietas Unggul Baru Padi. Inbrida Padi Sawah (INPARI), Hibrida Padi (HIPA), Inbrida Padi Gogo (INPAGO), Inbrida Padi Rawa(INPARA). In: Ali J, Satoto, P Sasmita, Y Baliadi, A Guswara and Suharna (eds). Deskripsi varietas unggul baru padi. Badan Penelitian dan Pengembangan Pertanian. Kementerian Pertanian, pp. 75-82. (in Indonesian).
ICFORD [Indonesia Center for Food Crops Research and Development]. 2017. Varietas Inpari 34 dan Inpari 35 Terbukti Tahan Salinitas. http:// pangan.litbang.pertanian.go.id/berita-887-varietasinpari-34-dan-inpari-35-terbukti-tahan-salinitas.html (Akses 24 Desember 2018)

ICFORD [Indonesian Center for Food Crops Research and Development]. 2019. Varietas Padi Toleran Kekeringan, Rendaman, Salinitas, dan Tahan Hama Penyakit Utama. http://www.litbang. pertanian.go.id/info-teknologi/2413/. (in Indonesian).

Djukri. 2009. Cekaman salinitas terhadap pertumbuhan tanaman. Di dalam: Prosiding Seminar Nasional Penelitian, Pendidikan dan Penerapan MIPA. FMIPA Universitas Negeri Yogyakarta, Yogyakarta. pp. 49-55. (in Indonesian).

Dogar UF, N Naila, A Maira, A Iqra, I Maryam, H Khalid, N Khalid, HS Ejaz and HB Khizar. 2012. Noxious effects of $\mathrm{NaCl}$ salinity on plants. Botany Res Inter 5: 20-23.

Erfandi, Deddy and A Rachman. 2011. Identification of Soil Salinity Due to Seawater Intrusion on Rice Field in the Northern Coas of Indramayu, West Java. $J$ Trop Soils 16: 115-121. doi 10.5400/jts.2011.16.2.115

Eviati and Sulaeman. 2012. Petunjuk Teknis Analisis Kimia Tanah, Tanaman, Air dan Pupuk. Edisi 2. Badan Litbang Pertanian. Kementerian Pertanian. 234p. (in Indonesian).

FAO [Food and Agricultural Organization]. 2005. Field guide: 20 things to know about the impact of salinity on agricultural land in Aceh Province, $8 \mathrm{p}$. www.fao.org/ag/tsunami/resources/info.html. Accesed on 26 July 2019.

Grattan SR and CM Grieve. 1999. Salinity-mineral nutrient relations in horticultural crops. Sci Hortic 78: 127-157.

Hariadi Y, K Marandon, Yu Tian, SE Jacobsen and S Shabala. 2010. Ionic and osmotic relations in quinoa (Chenopodium quinoa Willd.) plants grown at various salinity levels. $J$ Exp Bot 62:185-93.

Karimi E, AAbdolzadeh and HR Sadeghipour. 2009. Increasing salt tolerance in Olive, Olea Europaea L. plants by supplemental potassium nutriation involves changes in ion accumulation and anatomical attributes. Int J Plant Prod 3: 1735-6814.

Kronzucker HJ, D Coskun, LM Schulze, JR Wong and DT Britto. 2013. Sodium as nutrient and toxicant. Plant Soil 369: 1-23.

Kusmiyati F, ED Purbayanti and BA Kristanto. 2009. Karakter Fisiologi, Pertumbuhan dan Produksi Legum Pakan pada Kondisi Salin. In: LN Sumarsono, Mahfuds DW, Widjajanto, Karno E, Pangestu LN, Kustiawan TA, Sarjana and Surono (eds). Proceeding Seminar Nasional kebangkitan Peternakan, BP. Universitas Diponegoro, pp. 302308. (in Indonesian).

Las I, K Subagyono and AP Setiyanto. 2006. Isu dan pengelolaan lingkungan dalam revitalisasi pertanian. J Litbang Pertanian 25: 106-115. (in Indonesian). 
Makoi JHJR and H Verplancke. 2010. Effect of gypsum placement on the physical chemical properties of saline sandy loam soil. Aust J Crop Sci 4: 556-563.

Mindari W. 2009. Cekaman Garam dan Dampaknya pada Kesuburan Tanah dan Pertumbuhan Tanaman. Monograf. UPN "Veteran" Jawa Timur. 62p. (in Indonesian)

Motamed MK, R Asadi, M Rezaei and E Amiri. 2008. Response of high yielding rice varieties to $\mathrm{NaCl}$ salinity in greenhouse circumstances. Afr $J$ Biotechnol 7: 3866-3873.

Mozafar S, M Ghorbanli and H Ebrahimzadeh. 2007. Improved growth of salinity-stressed soybean after inoculation with salt pre-treated mycorrhizal fungi. J Plant Physiol 169: 1144-1151. doi: 10.1016/ j.jplph.2006.06.016

Muharam and A Saefudin. 2016. Pengaruh berbagai pembenah tanah terhadap pertumbuhan dan populasi tanaman padi sawah (Oryza sativa, L) Varietas Dendang di tanah salin sawah bukaan Baru. $J$ Agrotek Indonesia 1: 141-150. (in Indonesian).

Muliawan NRY. 2016. Identifikasi nilai salinitas pada lahan pertanian di daerah Jungkat berdasarkan metode daya hantar listrik (DHL). [Skripsi]. Fakultas Matematika dan Ilmu Pengetahuan Alam Universitas Tanjungpura, Pontianak. pp. 69-72. (in Indonesian).

Munns R. 2002. Comparative physiology of salt and water stress. J Plant Cell Env 25: 239-250.

Nawaz K, H Khalid, M Abdul, K Farah, A Shahid and A Kazim. 2010. Fatality of salt stress to plants: Morphological, physiological and biochemical aspects. review. Afr J Biotech 9: 5475-5480.

Oyiga BC, RC Sharma, J Shen, M Baum, FC Ogbonnaya, J Léon and A Ballvora. 2016. Identification and characterization of salt tolerance of wheat germplasm using a multivariable screening approach. J Agron Crop Sci 202: 472-485.

Rachman A, IGM Subiksa, D Erfandi and P Slavich. 2008. Dynamics of tsunami-affected soil properties. In: $F$ Agus and $G$ Tinning (eds). Proceeding of International Workshop on Post Tsunami Soil Management, pp. 51-64.

Rachmawati D. 2000. Tanggapan tanaman sorgum terhadap cekaman $\mathrm{NaCl}$ : Pertumbuhan dan osmoregulasi. Berkala Ilmiah Biologi. 2: 515-529.

Rad HE, F Aref, M Rezaei, E Amiri and M Khaledian. 2011. The effects of salinity at different growth stage on rice yield. Eco Env \& Cons 17: 111-117.

Ritung S, K Nugroho, A Mulyani and E Suryani. 2011. Petunjuk Teknis Evaluasi Lahan Untuk Komoditas Pertanian (Edisi Revisi). Balai Besar Penelitian dan Pengembangan Sumberdaya Lahan Pertanian, Badan Penelitian dan Pengembangan Pertanian, Bogor. 168p. (in Indonesian).

Roy SJ, S Negrão and M Tester. 2014. Salt resistant crop plants. Curr Opin Biotechnol 26: 115-124.

Rusd AMI. 2011. Pengujian toleransi padi (Oryza sativa L.) terhadap salinitas pada fase perkecambahan. [Skripsi]. Departemen Agronomi dan Hortikultura Institut Pertanian Bogor. (in Indonesian).
Sembiring H and A Gani. 2006. Adaptasi Varietas Padi Pada Tanah Terkena Tsunami. https:// www.dpi.nsw.gov.au/_data/assets/pdf_file/0009/ 199449/Adaptability-of-rice-on-tsunami-affectedsoil.pdf. Akses tanggal 24 Oktober 2019. (in Indonesian).

Sembiring H, A Gani and T Iskandar. 2008. Implications of salinity research in Aceh for indonesian rice growing. P. 97-108. In: F Agus and G. Tinning (eds). Proc of Inter. Workshop on Post Tsunami Soil Manag, $180 \mathrm{p}$.

Sembiring $\mathrm{H}$ and A Gani. 2010. Adaptasi Varietas Padi Pada Tanah Terkena Tsunami. Balai Besar Penelitian Tanaman Padi. 13p. (in Indonesian).

Shofiyanti R and Wahyunto. 2006. Inderaja untuk indetifikasi kerusakan lahan akibat tsunami dan rehabilitasinya. Warta Pertanian dan Pengembangan Pertanian 28: 18-19. (in Indonesian).

Sipayung R. 2003. Stres Garam dan Mekanisme Toleransi Tanaman. Universitas Sumatra Utara. Medan. (in Indonesian)

Sitompul SM and B Guritno. 1995. Analisis Pertumbuhan Tanaman. UGM Press, Yogyakarta. (in Indonesian).

Soil Research Institute. 2017. Petunjuk Penggunaan Perangkat Uji Tanah Rawa (PUTR). Versi 1.0. Balai Besar Litbang Sumberdaya Lahan Pertanian. Badan Litbang Pertanian. Kementerian Pertanian. 26p. (in Indonesian).

Steel RGD and IH Torrie. 1991. Prinsipdan Prosedur Statistika: Suatu Pendekatan Biometrik. PT. Gramedia, Jakarta. (Diterjemahkan oleh : B. Sumantri). (in Indonesian).

Suhartini T. 2004. Perbaikan Varietas Padi untuk Lahan Keracunan Fe. Buletin Plasma Nutfah. Balai Besar Penelitian dan Pengembangan Bioteknologi dan Sumberdaya Genetik Pertanian, Bogor. 11p. (in Indonesian).

Swapna TS. 2003. Salt stress induced changes on enzyme activities during different developmental stages of rice. Indian J Biotech 2: 251-258.

Syukri MN. 2009. Aplikasi Program Minitab 15: Statistika Untuk Perancangan Percobaan. Penerbit PT. Calprint Indonesia. 285p. (in Indonesian)

Utama MZH. 2015. Budidaya Padi pada Lahan Marjinal: Kiat Meningkatkan Produksi Padi. CV. Ando Offset. Yogyakarta 1.316p. (in Indonesian).

Wahyuningsih S, A Kristiono and A Taufik. 2017. Pengaruh Jenis Amelioran terhadap Pertumbuhan dan Hasil Kacang Hijau di Tanah Salin. Buletin Palawija 15: 69-77. (in Indonesian)

Widiarta IN. 2016. Teknologi Pengelolaan Tanaman Pangan dalam Beradaptasi Terhadap Perubahan Iklim pada Lahan Sawah. Makalah Review. Pusat Penelitian dan Pengembangan Tanaman Pangan, Bogor. pp. 91-102. (in Indonesian).

Xu S, S Zhu, Y Jiang, N Wang, R Wang, W Shen and J Yang. 2013. Hydrogen-rich water alleviates salt stress in rice during seed germination. Plant Soil 370:47-57. 